\title{
Efficiency of water use and nitrogen for goat milk production in irrigated pasture to different management
}

\author{
[Eficiência de uso de água e nitrogênio para produção de leite de cabra em pastagem \\ irrigada sob diferentes manejos] \\ A.C.R. Cavalcante ${ }^{1}$, P.M. Santos ${ }^{2}$, J.A.A.C. Júnior ${ }^{3}$, M.J.D. Cândido ${ }^{4}$, N.L.S. Lemos ${ }^{5}$ \\ ${ }^{1}$ Embrapa Caprinos e Ovinos, Sobral, CE \\ ${ }^{2}$ Embrapa Pecuária Sudeste, São Carlos, SP \\ ${ }^{3}$ Instituto Federal do Maranhão - Pinheiro, MA \\ ${ }^{4}$ Universidade Federal do Ceará - Fortaleza, CE \\ ${ }^{5}$ Universidade Federal de Sergipe - São Cristóvão, SE
}

\begin{abstract}
The aim was to determine the efficiency of use of water and nitrogen for forage production and goat-milk production on an irrigated Tanzania Guineagrass (Panicum maximum cv. Tanzânia) pasture subjected to different management practices. The management levels tested were combinations among nitrogen fertilization levels and post-grazing residual heights $\left(\operatorname{Res}_{\mathrm{H}}\right)$ : Intensive $\left(\operatorname{Res}_{\mathrm{H}}=33.0 \mathrm{~cm}\right.$ and $600.0 \mathrm{~kg} \mathrm{~N} /$ ha.year $\left.{ }^{-1}\right)$; Moderate

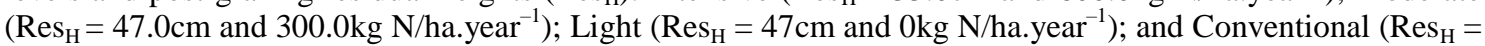
$33 \mathrm{~cm}$ and $0 \mathrm{~kg} \mathrm{~N} / \mathrm{ha} \mathrm{year}^{-1}$ ). The efficiency of water use for forage production was higher in intensive and Moderate management. The Conventional management was recommended only for forage production since there is no nitrogen input available because this result was similar to Intensive management in water efficiency. The efficiency of water use to produce goat milk was higher in Intensive management. Moderate management presented higher efficiency of nitrogen to produce forage. On the other hand, Intensive management was more efficient using nitrogen in goat milk production. The amount of water needed to produce one liter of goat milk varied from 893.20 to $3,933.50 \mathrm{~L}$. In the moderate management, up to $121.48 \mathrm{~kg}$ forage and $21.56 \mathrm{~kg}$ of milk were produced for every kilogram of $\mathrm{N}$ utilized. Intensive management is advantageous for water use efficiency as well nitrogen efficiency to produce goat milk in cultivated pasture.
\end{abstract}

Keywords: fertilization levels, forage dry matter, Tanzania Guinea Grass, residual height

\section{RESUMO}

Objetivou-se determinar a eficiência de uso de água e nitrogênio para a produção de forragem e de leite de cabra em pasto irrigado de capim-tanzânia, submetido a diferentes manejos. Os manejos testados foram combinações entre níveis de adubação nitrogenada e alturas residuais pós-pastejo $($ Alt $r)$ : intensivo $\left(\right.$ Alt $t_{r}=$ $\left.33,0 \mathrm{~cm} \mathrm{e} \mathrm{600,0kg} \mathrm{N/ha.ano}{ }^{-1}\right) ;$ moderado $\left(\right.$ Alt $r=47,0 \mathrm{~cm}$ e 300,0kg N/ha.ano $\left.{ }^{-1}\right)$; leve $\left(\right.$ Alt $t_{r}=47,0 \mathrm{~cm} \mathrm{e} 0 \mathrm{~kg}$ N/ha.ano ${ }^{-1}$ ) e convencional (Alt $t_{r}=33,0 \mathrm{~cm}$ e $0 \mathrm{~kg} \mathrm{~N} / \mathrm{ha}$.ano ${ }^{-1}$ ). A eficiência do uso de água para produção de forragem foi obtida nos manejos intensivo e moderado. O manejo convencional só foi interessante no caso da produção de forragem em situação de ausência de nitrogênio, não diferindo do manejo intensivo para a eficiência de uso de água. A eficiência de uso de água para a produção de leite foi maior no intensivo. A maior eficiência do uso de nitrogênio para produzir forragem foi no moderado, enquanto a maior eficiência de nitrogênio para a produção de leite foi no intensivo. A quantidade de água para produzir um litro de leite de cabra variou de 893,20 em manejo intensivo a 3.933,50L em convencional. Manejo intensivo é vantajoso para eficiência de uso de água e nitrogênio para a produção de forragem e de leite de cabra.

Palavras-chave: níveis de adubação, massa seca de forragem, Panicum maximum cv. Tanzânia, altura residual

Recebido em 18 de agosto de 2015

Aceito em 18 de fevereiro de 2016

E-mail: ana.clara@embrapa.br

Apoio financeiro: Banco do Nordeste e Embrapa 


\section{INTRODUCTION}

The sustainability of livestock production in semi-arid regions has led to the search for more efficient production models in the use of the natural resources that have a positive impact on the sustainable rural development of these regions. In this regard, dairy-goat farming has contributed to increasing the human development indices in semi-arid areas, especially in Brazil. This increase has been possible also through the use of technologies that make this production feasible economically and ecologically.

Some technological alternatives have been used to enable the animal production, with a minimum negative impact on the native pasture. Among these, the use of pastures cultivated in small areas, managed with irrigation and fertilization under rotational stocking, has provided great elevations in productivity, which characterizes it as a model for technically and economically viable production.

In the tropics, the scarcity of the water resource is the main constraint to production seasonality. The efficient use of this resource guarantees the sustainability, since a $1 \%$ increase in the efficiency of water in semi-arid climates would represent an economy of 200,000.0 L of water per hectare per year in agriculture, which is where $70 \%$ of the water on the planet is used (Oweis and Hachum, 2006).

Working with Tanzania Guinea grass pastures, Silva et al. (2007) produced up to $75.0 \mathrm{~kg}$ dry matter of forage with using $1 \mathrm{~mm}$ of water. Increased water productivity is directly related to the use of more efficient irrigation systems that consider climatic variables and plant water requirements (Oweis and Hachum, 2006, Mantovani et al., 2006). The use of nitrogen fertilization is one the most widely used tools to potentiate increases in production in irrigated areas, because of its effects on plant growth (Lemaire and Chapman, 1996).

According to Campos (2006), in a temperate climate, the production of $1.0 \mathrm{~kg}$ of cow milk implies consumption of approximately $10,000.00 \mathrm{~L}$ of water, and to produce $1.0 \mathrm{~kg}$ of beef, $20,000.00$ to $50,000.00 \mathrm{~L}$ of water are consumed. This total water volume is based on the need for production of pastures and concentrate feeds utilized by the cattle, besides the quantity ingested by the animals. That author emphasizes that in a tropical climate this intake may double.

The maintenance of sustainability in intensely exploited areas depends on the efficiency of resource use such as water and nitrogen, however, pasture factor is essential in the production system once that the use efficiency of such resources is measured through the forage production, and this depends on the intensity of grazing, in other words, of the post-grazing residue. According to Allen et al. (2011), residue is the forage remaining on the land after harvest.

The post-grazing residue is a primary factor in the management of pasture because directly influences the grazing frequency, grazing intensity, leaf renewal and, indirectly, the animal gain (Difante et al, 2010; Giacomini et al, 2009; Lana Souza et al, 2011).

Given the foregoing, the aim of this study was to determine the efficiency of water use and nitrogen for forage production and its effect on the production of milk by goats on an irrigated Tanzania Guinea grass pasture subjected to different management strategies.

\section{MATERIALS AND METHODS}

The experiment was conducted at Embrapa Goat and Sheep ( $3^{\circ} 40^{\prime} 58.42^{\prime \prime} \mathrm{S}$ latitude; $40^{\circ} 16^{\prime} 50.5^{\prime \prime}$ $\mathrm{W}$ longitude), located in Sobral/CE, Brazil, in an area with approximately 1.5 ha of pasture cultivated with Tanzania Guinea grass (Panicum maximum cv. Tanzânia) grazed under rotational stocking and a fixed low-pressure irrigation system $(0.2 \mathrm{Mpa})$ in the dry season, which comprises the months from August to December 2010. Climatic data of the experimental period are shown in Tab. 1. 
Table 1. Monthly climatic characteristics of the experimental environment from February 2009 to February $2010^{1}$

\begin{tabular}{cccccccccc} 
Month & MAXT & MINT & AVGT & RH $(\%)$ & WS & WDR & CLD* & PRP & EVP \\
\hline Aug/10 & 34.6 & 20.5 & 27.9 & 61 & 1.9 & 14 & 3.5 & 0 & 109 \\
Sep/10 & 36.3 & 21.6 & 30.3 & 54 & 2.9 & 13 & 3.2 & 0 & 126 \\
Oct/10 & 36.7 & 21.3 & 27.9 & 54 & 2.4 & 13 & 4.2 & 0 & 136 \\
Nov/10 & 36.2 & 21.9 & 30 & 52 & 2.9 & 11 & 3.8 & 0 & 126 \\
Dec/10 & 36.6 & 22.6 & 28.6 & 56 & 3.4 & 12 & 4.2 & 0 & 138 \\
\hline
\end{tabular}

${ }^{1}$ MAXT $=$ maximum temperature $\left({ }^{\circ} \mathrm{C}\right) ;$ MINT $=$ minimum temperature $\left({ }^{\circ} \mathrm{C}\right) ;$ AVGT $=$ average temperature $\left({ }^{\circ} \mathrm{C}\right) ; \mathrm{RH}$ = relative air humidity; $\mathrm{WS}=$ wind speed; $\mathrm{WDR}=$ wind direction; $\mathrm{CLD}=$ cloudiness; $\mathrm{PRP}=$ precipitation; $\mathrm{EVP}=$ evapotranspiration.

* CLD = cloudiness, varying from 1 to 10 , where 1 is a clear, cloudless sky, and 10 is a completely cloudy sky.

The predominant type of soil in the area, according to the new soil classification, is an Inceptisol (Santos et al., 2006; Campos and Queiroz, 2006). Prior to the onset of the experiment, soil analysis was performed in a sample collected at $0-30 \mathrm{~cm}$ depth aiming to characterize the soil fertility conditions. The soil was corrected and fertilized according to the grass requirement.

Fertilization for soil correction was applied to guarantee the establishment of the pasture, consisting of the application of $150 \mathrm{~kg}$ of urea/ha, $212 \mathrm{~kg}$ triple superphosphate/ha and $302 \mathrm{~kg}$ potassium chloride/ha, divided into two installments, corresponding to an input of $67.5 \mathrm{~kg}$ of nitrogen, $86.9 \mathrm{~kg}$ of phosphorus, and $175.19 \mathrm{~kg}$ of potassium.

The experimental design was completely randomized (CRD), with four replicates (paddocks) per treatment for the evaluations referring to pasture production. Milk production was also analyzed in a CRD, but with five replicates (animals) per treatment.

Treatments consisted of combinations among the nitrogen fertilization levels (source of urea) and post-grazing residual heights $\left(\mathrm{RES}_{\mathrm{H}}\right)$ : Intensive (600.0kg N ha ${ }^{-1} \cdot \mathrm{year}^{-1}$ and $33.0 \mathrm{~cm} \mathrm{RES}_{\mathrm{H}}$ ); Moderate $\left(300.0 \mathrm{~kg} \mathrm{~N} \mathrm{ha}^{-1} \cdot \mathrm{year}^{-1}\right.$ and $47.0 \mathrm{~cm}$ RES $\left._{\mathrm{H}}\right)$; Light $\left(0.0 \mathrm{~kg} \mathrm{~N} \mathrm{ha}{ }^{-1} \cdot\right.$ year $^{-1}$ and $47.0 \mathrm{~cm}$ $\left.\mathrm{RES}_{\mathrm{H}}\right)$; and Conventional $\left(0.0 \mathrm{~kg} \mathrm{~N} \mathrm{ha}{ }^{-1} \cdot\right.$ year $^{-1}$

$$
\text { EUW }\left(k g \text { TFDM.mm }{ }^{-1}\right)=\text { Y/V }
$$

where, EUW and EUN = efficiency of use of water and nitrogen in $\mathrm{kg}$ TFDM. $\mathrm{mm}^{-1}$ and $\mathrm{kg}$ TFDM.mm ${ }^{-1} ; \mathrm{Y}=$ total forage dry matter yield, kg TFDM ha ${ }^{-1}$ ); $\mathrm{V}=$ total water depth applied and $33.0 \mathrm{~cm} \mathrm{RES}_{\mathrm{H}}$ ). Fertilization was distributed throughout the experimental period according to the estimated number of grazing cycles. Within each grazing cycle, fertilization was split into two applications; the first one day after the animals left, and the second at the middle of the rest period.

The grazing method adopted was rotational stocking with variable stocking rate (Mott and Lucas, 1952). Stocking rate average was 70, 40, 30 and 20 goats per hectare in Intensive, Moderate, Light and Conventional management, respectively. The grazing period was fixed at four days and the rest period was variable. Rest was interrupted whenever the canopy intercepted $95 \pm 0.5 \%$ of the photosynthetically active radiation (Barbosa et al., 2007), using an AccuPAR LP-80 canopy analyzer (Decagon Devices Inc ${ }^{\circledR}$ ).

Sixty-four Anglo-Nubian goats were used; five test animals were used per treatment, and the rest were put-and-take animals, which were handled in the same way as the test animals. The used animals had average body weight of $44.0 \pm$ $1.0 \mathrm{~kg}$, milk yield of $0.374 \pm 0.34 \mathrm{~kg}$ milk per goat, and second-order calving.

The efficiencies of use of water and nitrogen for production of total forage dry matter (TFDM) were obtained using the following equation proposed by Oweis and Hachum, (2006):

\section{EUN $\left(\mathrm{kg} \mathrm{TFDM} \mathrm{N} \mathrm{kg}^{-1}\right)=\mathrm{Y} / \mathrm{N}$}

during the crop cycle, $\mathrm{mm} ; \mathrm{N}=$ total nitrogen applied during the crop cycle.

The forage matters utilized for the calculation were obtained by the estimate of the forage 
accumulation rate, expressed as TFDM in kg.ha${ }^{1}$.day $^{-1}$, through morphogenesis. To calculate the efficiency of use of nitrogen, the utilized mass was obtained as the difference between the masses of forage from the treatment without fertilization and those fertilized with the same residual height.

$$
\text { REUW (kg milk.mm } \left.{ }^{-1}\right)=M Y / V
$$

where REUW and REUN = relative efficiency of use of water and nitrogen in $\mathrm{kg}$ milk. $\mathrm{mm}^{-1}$ or $\mathrm{kg}$ milk.kg ${ }^{-1} ; \mathrm{MY}=$ milk yield, $\mathrm{kg} ; \mathrm{V}=$ total water depth applied during the crop cycle, $\mathrm{mm}$; $\mathrm{N}=$ total nitrogen applied during the evaluated period. Milk yield was obtained by daily measurements in two lactations of the analyzed period.

For the efficiency of the irrigation water, the water depth applied corresponding to the evapotranspiration of the culture was considered, obtained based on the reference evapotranspiration, which was estimated by the Penman-Monteith method (Allen et al., 1998). The crop coefficient adopted was 1.0, as proposed by Doorenbos and Kassan (1979). An application efficiency of $70 \%$ was used to obtain an average water depth of $3.4 \mathrm{~mm} \cdot \mathrm{day}^{-1}$. The daily application was performed during $1 \mathrm{~h} 40 \mathrm{~min}$, as the soil was physically characterized as shallow.

Data were subjected to analysis of variance and means were compared by Tukey's test at 5\% probability. The SAS 9.0 software was used for the statistical procedures.

\section{RESULTS AND DISCUSSION}

Greater efficiencies in the use of water for green dry forage production were quantified in the grazing intensities that received nitrogen fertilization, with 36.62 and $32.73 \mathrm{~kg}$ Green Forage Dry Matter (GFDM)/mm of water for the Moderate and Intensive managements, respectively. Tanzania Guinea grass is a kind of grass that has been used in intensive grazing systems because it has high capacity to biomass
The relative efficiency in the use of water and nitrogen (REUW and REUN) for milk production were obtained by the following formulae:

$$
\operatorname{REUN}\left(k g \text { milk.N kg }{ }^{-1}\right)=\mathrm{MY} / \mathrm{N}
$$

produce specially when receiving inputs as nitrogen and irrigated water. Other studies presented similar results with sheep production systems on pasture (Silva et al., 2007). Moderate and Intensive management can be used to promote efficiency in water use and nitrogen as well. (Tab. 2). There is another important result that we can see in table 2 , if there is not nitrogen available the Conventional management is recommended because this one is similar to the Intensive management considering EUW $_{\text {GFDM }}$. This recommendation is particularly interesting when smallholders are using area only to produce forage, especially during the rainy season when goats are used to browsing Caatinga vegetation.

The efficiency values in water use in the irrigation of the Tanzania Guinea grass for milk production were higher in the Intensive treatment, while in the other treatments production was similar (Tab. 2). This difference was expressive considering an average of $11.51 \mathrm{~L}$ by $\mathrm{mm}$ in intensive management against $3.58 \mathrm{~L}$ from others. These results demonstrate how much the intensification of management provides increments in the productive system. First of all, as Intensive management received high nitrogen input, more biomass was produced and more animals were necessary to get the goal postgrazing residual height. For this reason, goat milk production per hectare was highest in intensive management. This approach has a positive impact on efficiency use of water in goat milk production in Intensive management compared to the others. Finally, considering both efficiencies (forage and milk production) it seems that Intensive management is more adequate than others. 
Table 2. Mean values for efficiency in the use of water (EUW) for production of green forage dry matter $\left(E_{\text {GFDM }}\right)$ and goat milk $\left(E W_{M}\right)$ on Tanzania Guinea grass pasture subjected to different managements in the dry season under irrigation

\begin{tabular}{ccc}
\hline Management & $\operatorname{EUW}_{\mathrm{GFDM}}(\mathrm{kg} / \mathrm{mm})$ & $\mathrm{EUW}_{\mathrm{M}}(\mathrm{kg} \mathrm{milk} / \mathrm{mm})$ \\
\hline Intensive & $32.73 \mathrm{ab}^{1}$ & $11.51 \mathrm{a}$ \\
Moderate & $36.62 \mathrm{a}$ & $4.67 \mathrm{~b}$ \\
Light & $29.02 \mathrm{~b}$ & $2.83 \mathrm{~b}$ \\
Conventional & $26.59 \mathrm{~b}$ & $3.23 \mathrm{~b}$ \\
\hline
\end{tabular}

${ }^{1}$ Means followed by the same letter do not differ by Tukey's test $(\mathrm{P}>0.05)$.

The amount of water necessary to produce $1.0 \mathrm{~kg}$ of green forage varied between 273.97 and 386.56L (Tab. 3). There are not many data available about efficiency of use water in grasslands, whereas data from crops are more common. We are using crops to get a reference to understand and discuss some of our results. Tanzania Guinea grass consumed less water (386.56L) than corn culture $(1,400.00 \mathrm{~L})$ in same conditions, (Silva et al., 2007). Corn is one of the most popular crops used by farms to feed animals in dry lands during the dry season. Grains are very expensive to produce and use but sometimes are necessary because there are no other feed sources. Based on these results with Tanzania Guinea Grass, cultivated pastures can be another alternative to use small lands for grazing in places where water sources are available for irrigation, consequently reducing the amount of grains necessary during the dry season because it is possible to produce forage enough to feed the animals. This fact is noteworthy, since pastures in semi-arid areas can be more efficient in the use of water than the agricultural corn crop, which is the main energy source used in these regions, and to produce corn it is necessary to acquire machinery and man labor for cultivation and administration to animals, which raises the costs when compared with the grazing system.

The amount of water in kilogram and liters of milk from managements evaluated is showed in Table 3. Moderate and conventional management were different from forage dry matter production. Conventional management needed more water than moderate management. This last one probably needs less water than the other because its leaves are more efficient in the photosistesis process and reduced senescence because canopy is basically formed by young leaves, increasing biomass production (Cutrim Jr., et al. 2013). Working with guinea grass, Silva et al. (2007) obtained values between
$1,072.50$ and $1,413.60 \mathrm{~L}$ to produce one kilogram of forage in a rotational system. It should be stressed that the use of management strategies combining grazing intensities and nitrogen fertilization may increase this efficiency by up to seven times.

Table 3. Total amount of water required to produce one kilogram of total forage dry matter and one kilogram of milk in different managements

\begin{tabular}{|c|c|c|}
\hline Product & Management & $\begin{array}{c}\text { Water } \\
\text { requirement } \\
(\mathrm{L})\end{array}$ \\
\hline $\begin{array}{l}\text { Production of } \\
1.0 \mathrm{~kg} \text { of total } \\
\text { Tanzânia } \\
\text { Guineagrass } \\
\text { forage dry matter }\end{array}$ & $\begin{array}{l}\text { Intensive } \\
\text { Moderate } \\
\text { Light } \\
\text { Conventional }\end{array}$ & $\begin{array}{l}305.94 \mathrm{ab}^{1} \\
273.97 \mathrm{~b} \\
347.25 \mathrm{ab} \\
386.56 \mathrm{a}\end{array}$ \\
\hline $\begin{array}{l}\text { Production of } \\
1.0 \mathrm{~L} \text { of goat milk }\end{array}$ & $\begin{array}{l}\text { Intensive } \\
\text { Moderate } \\
\text { Light } \\
\text { Conventional }\end{array}$ & $\begin{array}{l}893.20 \mathrm{~b} \\
2,677.70 \mathrm{ab} \\
3,933.50 \mathrm{a} \\
3,270.60 \mathrm{ab}\end{array}$ \\
\hline
\end{tabular}

${ }^{\mathrm{I}}$ Means followed by the same letter do not differ by Tukey's test $(\mathrm{P}>0.05)$.

To produce $1.0 \mathrm{~kg}$ of goat milk it was necessary from 893.20 to $3,933.50 \mathrm{~L}$ of water. Intensive and light management were different $(\mathrm{P}<0.05)$. Light management spent four times more than intensive management to produce $1 \mathrm{~kg}$ of forage. The stocking rate combined with individual milk production was responsible for this result (Tab. 3).

Water is essential for plant development, and, associated with the fertilization technique, which is an accelerator of the plant physiological processes, it makes the system more efficient. According to Taiz and Zeiger (2006), water plays the role of carrying nutrients from the soil to the plant via mass flow or diffusion. In the plant, water performs a number of metabolic processes such as transpiration, which reduces the leaf 
temperature and ensures the gas exchange via stomata so that the photosynthetic processes can occur. When water is not the limiting factor, the use of nitrogen accelerates the growth rate of plants through the morphogenetic processes that occurs in the tiller (Lemaire and Chapman, 1996).

Some literature information pointed that milk production has more efficient water use than beef production (Campos, 2006; Silva et al. 2007). Around $10,000 \mathrm{~L}$ are to produce $10 \mathrm{~kg}$ dairy milk. Using the same amount of water it is only possible to produce $1 \mathrm{~kg}$ of beef cattle (Campos, 2006). In this same point of view, for small ruminant system production, 16,835 are necessary to produce $1.0 \mathrm{~kg}$ of sheep meat (Silva et al., 2007), whereas this same amount of water should be able to produce 191 of goat milk in the intensive management presented in this paper.
These results denoted that production of milk by grazing goats has great potential to be more efficient than products of other animal species. This fact demonstrated how interesting the dairygoat farming activity can for to the northeast region of Brazil, where water is scarce and milk is an equally important product as a food source and as a source of income generation for small properties.

The efficiency of conversion of nitrogen to green forage in the Moderate grazing was greater than that in the Intensive management. However, an increase in the level of nitrogen was expected to elevate green forage production, but this effect was suppressed (Tab. 4). Higher nitrogen amounts by urea sources are more susceptible leaching and volatilization losses especially in irrigated dry areas. This kind of impact is more expressive on biomass production.

Table 4. Relative efficiency of the use of nitrogen (REUN) for production of green forage dry matter $(\mathrm{kg} / \mathrm{kg} \mathrm{N})$ and milk $(\mathrm{kg} / \mathrm{kg} \mathrm{N})$ in the intensive and moderate managements

\begin{tabular}{lcc} 
Treatment & $\begin{array}{c}\text { REUN for green forage } \\
\text { production }\end{array}$ & REUN for milk production \\
\hline Intensive & $91.01 \mathrm{~b}^{1}$ & $29.52 \mathrm{a}$ \\
Moderate & $121.48 \mathrm{a}$ & $21.56 \mathrm{~b}$ \\
\hline
\end{tabular}

${ }^{1}$ Means followed by the same letter do not differ by Tukey's test $(\mathrm{P}>0.05)$.

Mello et al. (2008) obtained greater conversion efficiency of nitrogen into forage production with $307 \mathrm{~kg} / \mathrm{ha}$ for Panicum grass. These authors associated this response to a physiological limit of this type of plant to high nitrogen levels. Part of the nitrogen might also have volatilized; even though the application was divided in installments and there was irrigation, these strategies were not sufficient to reduce nitrogen losses.

Grazing Tanzania Guinea grass at a level similar to that tested in the intensive grazing, Silva et al. (2007) obtained a conversion efficiency of $80.0 \mathrm{~kg} \mathrm{DM}$ of forage $/ \mathrm{kg}$ of $\mathrm{N}$ applied. These values are very similar to that obtained in the present experiment, which proves the potential of using fertilization on forage production at the time of growth of the grass, regardless of the region. This result also demonstrates how responsive Tanzania Guinea grass is to intensive grazing under rotational stocking, irrigation, and fertilization, because elephant grass, a high-yield grass highly responsive to nitrogen fertilization, shows an efficiency of nitrogen use that varies from 56 to $65 \mathrm{DM} / \mathrm{kg}$ of applied $\mathrm{N}$.

Considering the efficiency in the use of nitrogen to produce milk, the reverse effect was obtained with the green forage so Intensive management was higher (Tab. 4). This result is probably closely related to stocking rate. Whereas intensive grazing has used 70 goats per hectare the moderate has used 40 goats per hectare, this aspect affecting milk production by hectare became more efficient in intensive management.

From the water and nitrogen efficiency point of view it seems that intensive management presents great advantage. Higher nitrogen amounts combined with an intensive grazing management should be an interesting tool to increase productivity in goat milk production systems. Rational use of natural resources and outside inputs could be a way for small systems of goat milk production to become viable by intensification of dry lands. 


\section{CONCLUSION}

Intensive management is advantageous for water use efficiency as well nitrogen efficiency to produce goat milk in cultivated pasture.

Conventional management is advantageous for forage production using water efficiently in situations when nitrogen input is not available.

\section{ACKNOWLEDGMENTS}

To Banco do Nordeste and Embrapa for the financial support granted for the experiment. To Professors Rodrigo Gregório da Silva (IFCELimoeiro do Norte), Teógenes Senna de Oliveira (UFC) and Fernando Mendonça (ESALQ) for the guidance and suggestions in the development of this study. To undergraduate research fellows Gutenberg Lira Silva, Tony Maiko Mesquita Oliveira and Elayne C.G. Vasconcelos for the support with data collection.

\section{REFERENCES}

ALLEN, R.G.; PEREIRA, L.S.; RAES, D. et al. Crop evapotranspiration: guidelines for computing crop water requirements. Rome: FAO, 1998. 300p. (Irrigation and drainage paper, 56).

ALLEN, V.G.; BATELLO, C.; BERRETA, E.J. et al. An international terminology for grazing lands and grazing animals. Grass Forage Sci., v.66, p.2-28, 2011

BARBOSA, R.A.; NASCIMENTO JR., D.; EUCLIDES, V.P.B.; et al. Capim-tanzânia submetido a combinações entre intensidade e frequência de pastejo. Pesqui. Agropecu. Bras., v.42, p.329-340, 2007.

CAMPOS, A.T. Instrução técnica para o produtor de leite: importância da água para bovinos de leite. Juiz de Fora: EMBRAPA Gado de Leite, 2006. 2p. (n.31).

CAMPOS, M.C.C.; QUEIROZ, S.B. Reclassificação dos perfis descritos no levantamento exploratórioreconhecimento de solos do estado da Paraíba. Rev. Biol. Ciênc. Terra, v.6, p.45-50, 2006.

CUTRIM JUNIOR, J.A.A.; CAVALCANTE, A.C.R.; CÂNDIDO, M.J.D. et al. Biomass flow in tifton-85 bermudagrass canopy subjected to different management strategies under rotational grazing with dairy goats. Rev. Bras. Zootec., v.42, p.77-86, 2013. (Online).
DIFANTE, G.S; EUCLIDES, V.P.B.; NASCIMENTO JR., D. et al. Desempenho e conversão alimentar e novilhos de corte em capim-tanzânia submetidos a duas intensidades de pastejo sob lotação rotativa. Rev. Bras. Zootec., v.39, p.33-41, 2010. (Online).

DOORENBOS, J.; KASSAN, A.H. Efectos del água sobre el redimento de los cultivos. Roma: FAO, 1979. 212p. (Riego y drenage, 33).

GIACOMINI, A.A.; SILVA, S.C.; SARMENTO, D.O.L. et al. Components of the leaf area index of marandu palisadegrass swards subjected to strategies of intermittent stocking. Sci. Agric., v.66, p.721-732, 2009.

LANA SOUSA, B.M.; NASCIMENTO JÚNIOR, D.; RODRIGUES, C.S. et al. Morphogenetic and structural characteristics of xaraes palisadegrass submitted to cutting heights. Rev. Bras. Zootec., v.40, p.53-59, 2011.

LEMAIRE, G.; CHAPMAN, D.F. Tissue flows in grazed plants communities. In: HODGSON, J.; ILLUS, A.W. (Eds.). The ecology and management of grazing systems. London: CAB International, 1996. p.3-36.

MANTOVANI, E.C.; BERNARDO, S.; PALARETTI, L.F. Irrigação: princípios e métodos. Viçosa: UFV, 2006. 318p.

MELLO, S.Q.S.; FRANÇA, A.F.S; LANNA, A.C. $e t$ al. Adubação nitrogenada em capim-mombaça: produção, eficiência de conversão e recuperação aparente do nitrogênio. Ciênc. Anim. Bras., v.9, p.935947, 2008

MOTT, G.O.; LUCAS, H.L. The design conduct and interpretation of grazing trials on cultivated and improved pastures. In: INTERNATIONAL GRASSLAND CONGRESS, 6., 1952, Pensylvania. Proceedings... Pensylvania: State College Press, 1952. p.1380-1395.

OWEIS, T.; HACHUM, A. From water use efficiency to water productivity: issues of research and development. In: WATER USE EFFICINCY NETWORK, 1., 2006, Aleppo. Proceedings... Aleppo: ICARDA, 2006. p.13-38.

SANTOS, H.G.; JACOMINE, P.K.T.; ANJOS, L.H.C. et al. Sistema brasileiro de classificação de solos. 2.ed. Rio de Janeiro: Embrapa Solos, 2006. 306p.

SILVA, R.G.; MONTEIRO, R.O.C.; CHAVES, S.W.P. et al. Eficiência no uso da água e do nitrogênio na produção do capim tanzânia em sistema de pastejo rotacionado de ovinos. Eng. Rural, v.18, p.69-75, 2007

TAIZ, L.; ZAIGER, E. Plant physiology. 4.ed. Massachusetts: Sinauer Associates, 2006. 764p. 